\author{
JOURNAL OF MARINE RESEARCH AND TECHNOLOGY \\ journal homepage: https://ojs.unud.ac.id/index.php/JMRT \\ ISSN: 2621-0096 (electronic); 2621-0088 (print)
}

\title{
Simpanan Karbon Padang Lamun di Perairan Pantai Nusa Lembongan, Klungkung, Bali
}

\author{
I Ketut Suta Negara ${ }^{\text {a }}$ I Wayan Gede Astawa Karang*a ${ }^{*}$ I Nyoman Giri Putra ${ }^{a}$
}

${ }^{a}$ Program Studi Ilmu Kelautan, Fakultas Kelautan dan Perikanan, Universitas Udayana, Bali, Indonesia

*Corresponding author, email: gedekarang@unud.ac.id

\section{ARTICLE INFO

\author{
ABSTRACT
}

\section{Article history:}

Received: June $8^{\text {th }} 2020$

Received in revised form: July $14^{\text {th }} 2020$

Accepted: August $6^{\text {th }} 2020$

Available online: August $31^{\text {th }} 2020$

Keywords:

Biomass

Carbon Storage

Coastal Area

Nusa Lembongan

Seagrass

\begin{abstract}
The seagrass ecosystem has great potential in absorbing of $\mathrm{CO}_{2}$ concentration in atmosphere, results of the process photosynthesis will be stored in form of biomass during seagrass still alive. The research purpose was to know carbon storage from the seagrass ecosystem at the top substrate (leaves) and bottom substrates (rhizome and roots) in Nusa Lembongan coastal area, Bali. The research location is divided into three stations with 27 points-Carbon stock was analyzed by using invasion method consisting of calculating the value of ash content, organic matter content and carbon content. The results found three seagrass species in the Nusa Lembongan coastal area: Thalassia hemprichii, Cymodocea rotundata and Enhalus acoroides. The most dominant spesies is the Thalassia hemprichii. The carbon stored at the top substrate (leaf) is $21.08 \mathrm{gC} / \mathrm{m}^{2}$ and the bottom substrates (rhizome and root) are $52.67 \mathrm{gC} / \mathrm{m}^{2}$. The total estimated carbon deposits in the Nusa Lembongan coastal area is 65.98 tonnes with carbon deposits in the bottom substrate are larger than the top substrate, which is $71 \%$ or 47.12 tons on the bottom substrate while $29 \%$ or 18.86 tons on the top substrate.
\end{abstract}

2020 JMRT. All right reserved.

\section{Pendahuluan}

Ekosistem lamun merupakan salah satu ekosistem yang penting di wilayah pesisir selain ekosistem mangrove dan terumbu karang. Proses fotosintesis pada ekosistem lamun memiliki potensi besar dalam menyerap $\mathrm{CO}_{2}$ di atmosfer. Menurut Graha et al. (2016) hasil dari proses fotosintesis berupa biomassa akan disimpan selama lamun tersebut masih hidup dalam waktu yang lama. Ekosistem lamun bersama dengan ekosistem mangrove dan rawa payau dapat menangkap sekitar $50 \%$ sampai $70 \%$ dari karbon organik yang berada di lautan, dengan penyerapan karbon sebesar 235 sampai $450 \mathrm{Tg} \mathrm{C} / \mathrm{tahun}$ (Fourqurean et al., 2012)

Penyerapan karbon pada lamun melalui proses fotosintesis dengan bantuan sinar matahari akan mengahasilkan bahan organik dari bahan anorganik, hasil penyerapan karbon tersebut disimpan berupa biomassa dibagian atas substrat seperti daun maupun dibagian bawah substrat (rhizoma dan akar) (Supriadi et al., 2014). Penyerapan sebagian karbon oleh lamun dimanfaatkan sebagai energi dan sebagiannya tersimpan sebagai biomassa pada jaringan lamun (Khairunnisa et al., 2018). Potensi simpanan karbon di bawah substrat akan disimpan dan terkunci pada sedimen walaupun lamun mengalami kematian, sedangkan karbon dibagian atas substrat akan tersimpan hanya saat lamun hidup (Kennedy \& Bjork, 2009).

Penelitian potensi simpanan karbon padang lamun sendiri telah banyak dilakukan Campbell et al. (2015) simpanan karbon padang lamun di Abu Dhabi, United Arab Emirates. Githaiga et al. (2017) simpanan karbon padang lamun di Gazi Bay, Kenya. Fourqurean et al. (2012) Ekosistem lamun sebagai penyimpan karbon secara global. Khusus di Indonesia telah dilakukan oleh
Irawan (2017) menemukan bahwa lamun dapat menyerap karbon $133,24 \mathrm{gC} / \mathrm{m}^{2}$ sampai $133,71 \mathrm{gC} / \mathrm{m}^{2}$ pada bagian atas maupun bagian bawah substrat di Pulau Bintang. Hartanti et al. (2017) mengemukakan bahwa penyerapan karbon lamun di Pulau Menjangan Kecil sebesar 193,31 $\mathrm{gC} / \mathrm{m}^{2}$ pada bawah substrat lebih tinggi dari atas substart sebesar $119,99 \mathrm{gC} / \mathrm{m}^{2}$. Rahman et al. (2018) mengemukakan bahwa penyimpanan karbon lamun di Perairan Poton Baku bagian atas substrat sebesar 142,77 gC/m dan $305,15 \mathrm{gC} / \mathrm{m}^{2}$ pada bawah substrat.

Penelitian kandungan karbon lamun di Bali telah dilakukan salah satunya di kawasan Pantai Mengiat dimana hasil dari penelitian tersebut menyatakan bahwa kandungan karbon atas substrat sebesar $17,18 \mathrm{gC} / \mathrm{m}^{2}$ sedangkan untuk bawah substrat mengandung karbon sebesar $25,70 \mathrm{gC} / \mathrm{m}^{2}$ (Rahadiarta et al., 2018). Graha et al. (2016) menyatakan bahwa kandungan karbon lamun di Pantai Sanur berbanding lurus dengan biomassa lamun. Pada penelitian ini diketahui biomassa lamun bawah substrat sebesar 9,92 - 145,67 $\mathrm{gbk} / \mathrm{m}^{2}$ dengan penyimpanan karbon sebesar 1,62 - 29,54 $\mathrm{gC} / \mathrm{m}^{2}$ lebih besar dari biomassa atas substrat sebesar $16,08-97,17 \mathrm{gbk} / \mathrm{m}^{2}$ dengan simpanan karbon sebesar 3,21 -18,10 gC/m².

Kawasan Konservasi Perairan (KKP) Nusa Penida memiliki berbagai jenis biota laut salah satunya adalah keanekaragaman pada ekosistem lamun dimana sebagian besar dari ekosistem lamun tersebut terdapat di Nusa lembongan yang merupakan salah satu wilayah dari Konservasi Nusa Penida (KKP, 2010). KKP Nusa Penida sendiri memiliki ekosistem padang lamun seluas $108 \mathrm{Ha}$, ekosistem hutan bakau seluas $23 \mathrm{Ha}$ dan ekosistem terumbu karang $1419 \mathrm{Ha}$.

Pramudya et al. (2014) telah melakukan penelitian mengenai padang lamun di Nusa Lembongan menggunakan citra satelit 
LANDSAT 8 dimana hasil dari penelitian tersebut menemukan luasan padang lamun di Nusa Lembongan sebesar 776,600 m². Pharmawati et al. (2015) mengenai keanekaragaman genetik Enhalus acoroides dari 3 perairan yang berbeda yaitu salah satunya di Perairan Nusa Lembongan dan Astaman (2019) menggunakan citra satelit SPOT-7 dimana hasil dari penelitian tersebut menyebutkan bahwa luasan padang lamun di Nusa Lembongan sebesar 89,64 Ha. Sedangkan penelitian potensi simpanan karbon padang lamun di Nusa Lembongan saat ini belum pernah dilakukan. Mengingat lamun memiliki potensi besar dalam mengurangi konsentrasi $\mathrm{CO}_{2}$ di atmosfer untuk mengurangi dampak dari pemanasan global, maka dari itu perlu dilakukan suatu perhitungan mengenai estimasi potensi simpanan karbon bagian atas dan bawah substrat pada lamun di Perairan Pantai Nusa Lembongan.

\section{Metode}

\subsection{Lokasi Penelitian}

Penelitian bertempat di Nusa Lembongan, Kabupaten Klungkung, Provinsi Bali. Data lapangan diambil pada bulan Agustus 2019, dimana terdapat tiga stasiun penelitian dan pada setiap stasiunnya terdapat sembilan titik pengamatan sehingga jumlah titik pengamatan sebanyak 27 titik. Stasiun 1 bertempat di bagian barat pulau Nusa Lembongan, untuk stasiun 2 bertempat di utara pulau Nusa Lembongan dan untuk stasiun 3 bertempat di bagian timur pulau Nusa Lembongan, pemilihan stasiun tersebut berdasarkan pada luasan hamparan lamun dan akses menuju pantai (Gambar. 1). Titik pengambilan sampel ditentukan secara purposive sampling berdasarkan keberadaan lamun yang digunakan untuk perhitungan persamaan kerapatan, biomassa dan kandungan karbon lamun. Pengamatan lapangan yang dilakukan meliputi pengamatan jenis lamun, kerapatan lamun serta sampel biomassa lamun, terdapat dua kategori biomassa lamun yaitu biomassa bawah substrat (rhizoma dan akar) serta biomassa atas substrat (daun).

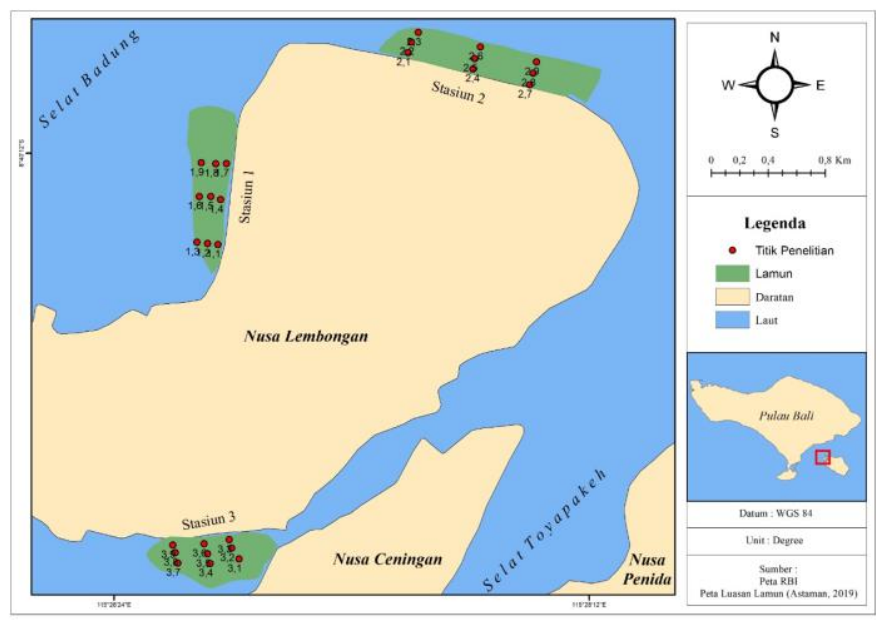

Gambar 1. Peta Penelitian

\subsection{Prosedur Penelitian}

\subsubsection{Metode Pengambilan Sampel}

Kerapatan lamun didapat dari menghitung jumlah individu lamun yang berada pada transek kuadrat dengan ukuran 50 x 50 $\mathrm{cm}$. Awal peletakan transek kuadrat disesuaikan dengan awal ditemukannya lamun. Pengambilan sampel biomassa lamun bersamaan dengan pengambilan data kerapatan lamun. Sampel biomassa lamun untuk perhitungan biomassa didapatkan dari lamun yang berada di dalam transek kemudian diambil sampai kedalam penetrasi akar dengan menggunakan sekop serta dilakukan pemotongan pada rhizoma lamun yang menjalar sampai luar transek. Sampel kemudian dimasukkan ke dalam coolbox untuk menjaga kesegaran lamun.

\subsubsection{Pengolahan Sampel}

\subsubsection{Biomassa Lamun}

Pengolahan sampel biomassa lamun berdasarkan Azkab (1999). Sampel biomassa lamun dibersihkan dengan air tawar setelah itu dipisahkan berdasarkan jenis pada setiap stasiunnya. Sampel lamun dibagi mejadi 2 bagian yaitu daun untuk atas substrat sedangkan rhizoma dan akar untuk bagian bawah substrat. Kemudian sampel yang sudah dipisahkan tersebut dikeringkan di dalam dry oven selama 24 jam pada temperatur $60^{\circ} \mathrm{C}$. Selanjutnya sampel lamun yang sudah kering ditimbang dengan menggunakan necara analitik.

\subsubsection{Kandungan Karbon}

Perhitungan kandungan karbon lamun pada penelitian ini merujuk kapada metode pengabuan Helrich. (1990), dimana cawan porselin yang sudah dibersihkan kemudian dimasukkan ke tanur listrik dengan temperatur $500^{\circ} \mathrm{C}$ selama $2-3$ jam, kemudian timbang dan catat cawan sebegai cawan kosong. Masukkan 2 gram sampel lamun kering pada cawan kemudian timbang dan catat sebagai berat cawan + berat sampel. Setelah itu cawan yang berisi sampel tersebut dibakar pada tanur listrik dengan temperatur $500^{\circ} \mathrm{C}$ selama 6 jam $500^{\circ} \mathrm{C}$ hingga berubah menjadi abu kemudian timbang dan catat sebagai berat cawan + berat abu.

\subsection{Analisis Data}

\subsubsection{Komposisi Jenis Lamun}

Perhitungan komposisi jenis lamun merujuk pada Fachrul (2007) dengan persamaan (1) :

$K j=\frac{n i}{N} \times 100 \%$

dengan keterangan $\mathrm{Kj}$ : Komposisi jenis (\%), N: Jumlah seluruh jenis (ind), ni : Jumlah Jenis Ke-i (ind)

\subsubsection{Kerapatan Lamun}

Perhitungan nilai kerapatan lamun merujuk pada Khouw (2009) dengan persamaan (2) :

$$
D i=\frac{n_{i}}{A}
$$

dengan keterangan :

$\mathrm{D}_{\mathrm{i}}$ : Kerapatan lamun jenis-i (ind $/ \mathrm{m}^{2}$ )

$\mathrm{n}_{\mathrm{i}}$ : Jumlah tegakan lamun jenis ke-i

A : Jumlah luas transek ditemukannya lamun jenis-i $\left(\mathrm{m}^{2}\right)$

Kondisi kerapatan lamun dapat diklasifikasikan menjadi lima skala seperti pada (Tabel 1).

Tabel 1. Skala Kondisi Padang Lamun Berdasarkan Kerapatan

\begin{tabular}{ccc}
\hline Skala & Kerapatan $\left(\mathrm{ind} / \mathrm{m}^{2}\right)$ & Kondisi \\
\hline 1 & $<25$ & Sangat jarang \\
2 & $25-224$ & Jarang \\
3 & $225-424$ & Agak rapat \\
4 & $425-624$ & Rapat \\
5 & $>625$ & Sangat rapat \\
\hline
\end{tabular}

Sumber : Nurzahraeni, 2014 


\subsubsection{Biomassa Lamun}

Perhitungan nilai biomassa lamun didapat dari berat kering lamun yang dibagi dengan luasan area yang merujuk pada Howard et al. (2014) dengan persamaan (3) :

$B=W / A$

dengan keterangan $B$ : Biomassa lamun $\left(\mathrm{gbk} / \mathrm{m}^{2}\right), A$ : Luas area $\left(\mathrm{m}^{2}\right), W$ : Berat kering lamun (gbk).

\subsubsection{Kandungan Karbon}

Nilai kandungan karbon lamun didapat dari analisis metode pengabuan (Helrich, 1990), dimana pada metode ini terdapat tiga perhitungan yaitu perhitungan nilai kadar abu, perhitungan nilai kandungan bahan organik serta perhitungan nilai kandungan karbon

Perhitungan nilai kadar abu menggunakan persamaan (4) (Helrich, 1990) :

Kadar $a b u=\frac{c-a}{b-a} \times 100 \%$

Selanjutnya, untuk mengetahui nilai kadar bahan organik yang terdapat di jaringan lamun dihitung menggunakan persamaan (5) (Helrich, 1990) :

Kadar Bahan organik $=\frac{[(b-a)-(c-a)]}{(b-a)} \times 100 \%$

dengan keterangan berat cawan (a), berat cawan + berat sampel $(b)$ dan berat cawan + berat abu $(c)$.

Perhitungan nilai kandungan karbon menggunakan persamaan (6) (Helrich, 1990) :

Kandungan Karbon = Bahan Organik / 1,724

dimana 1,724 adalah konstanta nilai bahan organik

Sementara itu untuk mengetahui estimasi simpanan karbon (carbon stock) dihitung dengan mengkonversi nilai kandungan karbon dengan luas area lamun (Indriani et al., 2017).

\section{Hasil}

\subsection{Deskripsi Lokasi Penelitian dan Komposisi Jenis Lamun}

Ekosistem padang lamun di perairan Pantai Nusa Lembongan berbentuk hamparan lamun yang cukup luas dimana sebagian besar jenis substratnya adalah substrat berpasir dan pasir berlumpur. Secara umum tiga lokasi penelitian merupakan tujuan wisata dan banyak terdapat aktivitas manusia di pantai.

Pada stasiun 1 merupakan tempat untuk penambatan kapal transportasi penyeberangan maupun untuk keperluan pariwisata, jenis substrat pada stasiun ini adalah substrat berpasir. Pada stasiun ini ditemukan jenis lamun Thalassia hemprichii dan Cymodocea rotundata. Pada stasiun 2 juga merupakan tempat penambatan kapal untuk keperluan pariwisata, pada stasiun ini ekosistem lamun hidup berdampingan dengan eskositem mangrove dan juga terumbu karang, sehingga terdapat dua jenis substrat yang ditemukan yaitu pasir berlumpur dan pasir dengan pecahan karang. Tiga jenis lamun ditemukan pada stasiun ini antara lain jenis Thalassia hemprichii, Cymodocea rotundata serta Enhalus acoroides. Pada stasiun 3 merupakan daerah yang dulunya digunakan untuk lahan bertani rumput laut, hal tersebut dapat dilihat dari banyaknya patok - patok kayu yang tertancap di wilayah ini, dimana pada stasiun ini ditemukan lamun jenis Cymodocea rotundata dan Thalassia hemprichii dengan jenis substrat yang mendominasi adalah jenis substrat pasir berlumpur.
Thalassia hemprichii memiliki nilai komposisi jenis tertinggi dari tiga stasiun penelitian yaitu sebesar $68 \%$ dimana jenis ini hampir ditemukan pada 27 titik pengamatan, kemudian diikuti oleh jenis Cymodocea rotundata sebesar 31\% dan lamun yang memiliki komposisi jenis terendah adalah jenis Enhalus acoroides dengan nilai komposisi jenis hanya sebesar $1 \%$, nilai yang rendah tersebut dikarenakan jenis ini ditemukan hanya di tiga titik dari 27 titik penelitian yaitu pada titik yang berdekatan dengan ekosistem mangrove, jenis lamun Enhalus acoroides merupakan jenis lamun yang memiliki nilai kerapatan paling rendah di antara dua jenis lainnya (Gambar. 2).

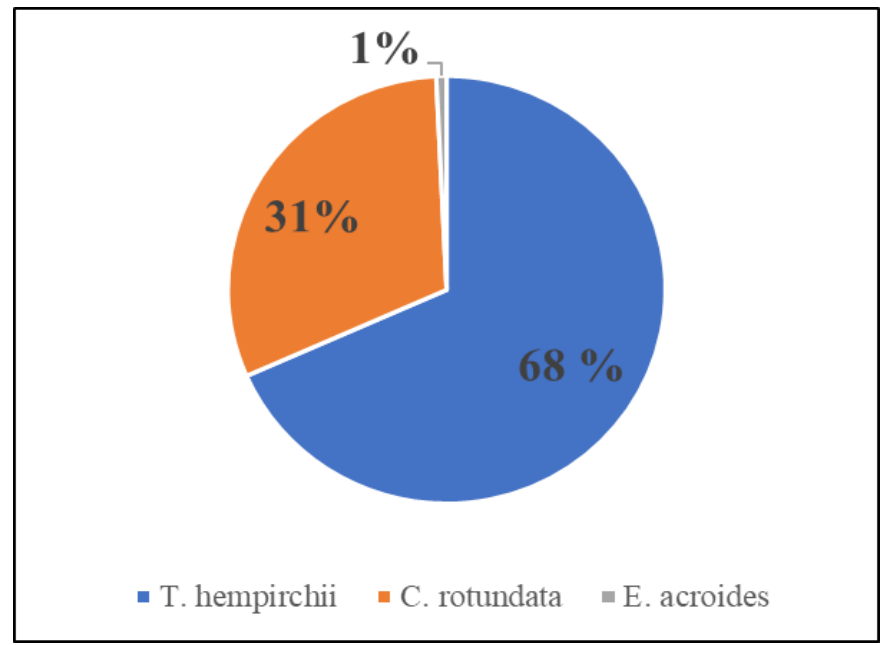

Gambar 2. Komposisi Jenis Lamun

\subsection{Kerapatan Lamun}

Thalassia hemprichii merupakan jenis lamun yang memiliki kerapatan tertinggi dari 27 titik pengamatan dengan rata - rata $397 \mathrm{ind} / \mathrm{m}^{2}$ dan jenis ini merupakan jenis yang paling sering ditemukan dan terdapat pada semua stasiun penelitian, kemudian disusul oleh jenis Cymodocea rotundata dengan rata - rata kerapatan sebesar $179 \mathrm{ind} / \mathrm{m}^{2}$ sedangkan jenis lamun yang memiliki rata - rata kerapatan paling rendah dari 27 titik pengamatan adalah jenis Enhalus acoroides sebesar $4 \mathrm{ind} / \mathrm{m}^{2}$ yang hanya ditemukan pada tiga titik pengamatan di stasiun 2 .

Kerapatan stasiun tertinggi dari tiga stasiun penelitian terdapat pada stasiun 1, dimana pada stasiun ini terdapat dua jenis lamun yang ditemukan yaitu jenis Thalassia hemprichii dengan kerapatan jenis sebesar 208 - $912 \mathrm{ind} / \mathrm{m}^{2}$ dan jenis Cymodocea rotundata dengan kerapatan jenis sebesar $144-728 \mathrm{ind} / \mathrm{m}^{2}$, jenis lamun Thalassia hemprichii pada stasiun ini lebih mendominasi daripada jenis Cymodocea rotundata karena jenis Thalassia hemprichii lebih sering ditemukan pada sembilan titik pengamatan di stasiun 1 jenis ini juga memiliki nilai kerapatan jenis lebih tinggi dibandingkan jenis Cymodocea rotundata. Total kerapatan lamun di stasiun 1 yaitu sebesar $614 \mathrm{ind} / \mathrm{m}^{2}$ dimana nilai ini menunjukkan skala kondisi kerapatan lamun yang rapat, jenis substrat yang mendominasi pada stasiun ini adalah jenis substrat berpasir.

Jenis lamun Thalassia hemprichii, Cymodocea rotundata serta Enhalus acoroides ditemukan pada stasiun 2. Thalassia hemprichii merupakan jenis lamun yang paling sering ditemukan dengan kerapatan jenis sebesar $64-752 \mathrm{ind} / \mathrm{m}^{2}$ dan Cymodocea rotundata dengan kerapatan jenis sebesar $160-880 \mathrm{ind} / \mathrm{m}^{2}$, sedangkan untuk jenis Enhalus acoroides merupakan jenis yang paling jarang ditemukan dengan kerapatan jens sebesar $24-48$ ind $/ \mathrm{m}^{2}$, dari tiga stasiun penelitian jenis ini hanya ditemukan pada stasiun dua, pada titik $2.7,2.8$ dan 2.9, ketiga titik ini merupakan titik yang dekat dengan ekosistem mangrove. Total 
kerapatan lamun pada stasiun ini sebesar $527 \mathrm{ind} / \mathrm{m}^{2}$ dimana nilai ini menunjukkan skala kondisi rapat, jenis substrat pada stasiun ini adalah pasir dengan pecahan karang dan pasir berlumpur.

Jenis lamun Thalassia hemprichii dan Cymodocea rotundata merupakan jenis lamun yang ditemukan pada stasiun 3. Thalassia hemprichii memiliki kerapatan jenis sebesar $72-868$ ind $/ \mathrm{m}^{2}$ dimana jenis ini lebih mendominasi dibandingkan jenis Cymodocea rotundata memiliki kerapatan jenis sebesar 136 $628 \mathrm{ind} / \mathrm{m}^{2}$. Total kerapatam lamun pada stasiun ini sebesar 600 $\mathrm{ind} / \mathrm{m}^{2}$ dimana nilai ini menunjukkan skala kondisi rapat, pada stasiun ini jenis substrat yang mendominasi adalah jenis subsrat pasir berlumpur.

Tabel 2. Kerapatan Lamun

\begin{tabular}{|c|c|c|c|c|c|}
\hline \multirow{2}{*}{ Stasiun } & \multicolumn{3}{|c|}{ Jenis Lamun } & \multirow{2}{*}{$\begin{array}{c}\text { Rata-Rata } \\
\text { Kerapatan } \\
\left(\text { tegakan } / \mathrm{m}^{2} \text { ) }\right.\end{array}$} & \multirow{2}{*}{$\begin{array}{c}\text { Skala } \\
\text { Kondisi }\end{array}$} \\
\hline & $\begin{array}{c}\text { Thalassia } \\
\text { hemprichii }\end{array}$ & $\begin{array}{l}\text { Cymodocea } \\
\text { rotundata }\end{array}$ & $\begin{array}{c}\text { Enhalus } \\
\text { acoroides }\end{array}$ & & \\
\hline \multirow{9}{*}{1} & 912 & - & - & \multirow{9}{*}{614} & \multirow{9}{*}{ Rapat } \\
\hline & 408 & 168 & - & & \\
\hline & 544 & 144 & - & & \\
\hline & - & 496 & - & & \\
\hline & 208 & - & - & & \\
\hline & 864 & - & - & & \\
\hline & - & 728 & - & & \\
\hline & 764 & - & - & & \\
\hline & 288 & - & - & & \\
\hline \multirow{9}{*}{2} & - & 880 & - & \multirow{9}{*}{527} & \multirow{9}{*}{ Rapat } \\
\hline & 344 & 296 & - & & \\
\hline & 752 & - & - & & \\
\hline & 316 & 284 & - & & \\
\hline & 424 & - & - & & \\
\hline & 416 & - & - & & \\
\hline & 340 & 160 & 24 & & \\
\hline & 64 & - & 48 & & \\
\hline & 344 & - & 48 & & \\
\hline \multirow{9}{*}{3} & 868 & - & - & \multirow{9}{*}{600} & \multirow{9}{*}{ Rapat } \\
\hline & 456 & - & - & & \\
\hline & 432 & - & - & & \\
\hline & 72 & 348 & - & & \\
\hline & 148 & 236 & - & & \\
\hline & - & 628 & - & & \\
\hline & 560 & 136 & - & & \\
\hline & 444 & 324 & - & & \\
\hline & 744 & - & - & & \\
\hline Total & 397 & 179 & 4 & 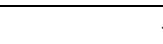 & \\
\hline
\end{tabular}

\subsection{Biomassa Lamun}

Pada penelitian ini nilai biomassa yang besar diperoleh dari jenis lamun Thalassia hemprichii karena jenis lamun ini ditemukan di semua stasiun penelitian dengan nilai kerapatan tertinggi dibandingkan jenis lainya, sedangkan nilai biomassa terkecil diperoleh dari jenis Enhalus acoroides yang hanya ditemukan pada stasiun 2 dan memiliki nilai kerapatan paling rendah.

Secara umum, biomassa lamun di bagian bawah substrat lebih tinggi dibandingkan bagian atas substrat pada ketiga stasiun penelitian. Pada stasiun 1 nilai biomassa bagian bawah substrat sebesar $477,11 \mathrm{gbk} / \mathrm{m}^{2}$ lebih tinggi dari pada biomassa di atas substrat sebesar $310,75 \mathrm{gbk} / \mathrm{m}^{2}$, pada stasiun ini ditemukan dua jenis lamun antara lain jenis Thalassia hemprichii dan Cymodocea rotundata. Pada stasiun 2 nilai biomassa lamu pada bagian bawah substrat sebesar $648,39 \mathrm{gbk} / \mathrm{m}^{2}$ lebih tinggi dibandingkan biomassa pada bagian atas substrat sebesar 157,38 $\mathrm{gbk} / \mathrm{m}^{2}$, pada stasiun ini ditemukan tiga jenis lamun yaitu Thalassia hemprichii, Cymodocea rotundata dan Enhalus acoroides. Pada stasiun 3 nilai biomassa pada bagian bawah susbtrat sebesar $479,12 \mathrm{gbk} / \mathrm{m}^{2}$ lebih tinggi dibandingkan nilai biomassa pada bagian atas substrat sebesar $275,55 \mathrm{gbk} / \mathrm{m}^{2}$, pada stasiun ini ditemukan dua jenis lamun antara lain Thalassia hemprichii dan Cymodocea rotundata. Biomassa lamun perstasiun ditampilkan pada Gambar 3.

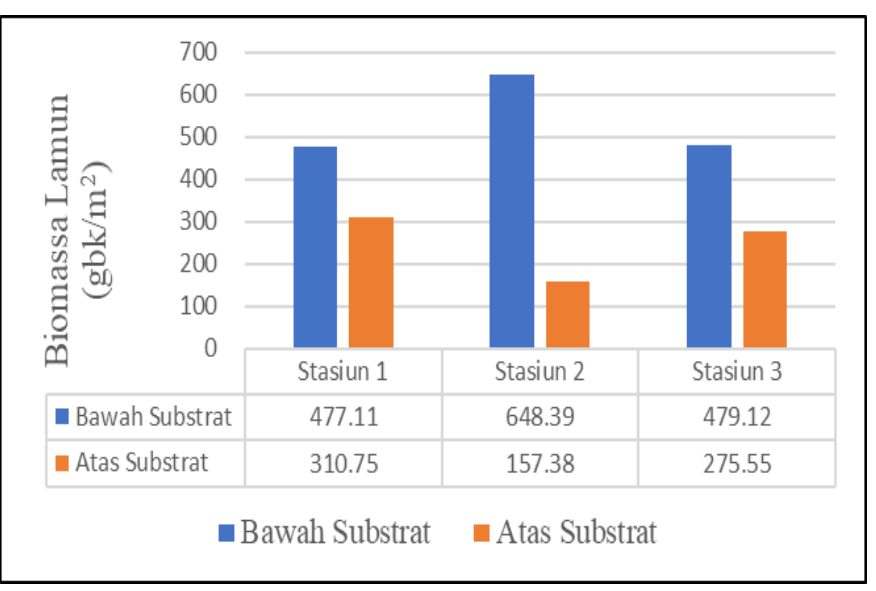

Gambar 3. Biomassa Lamun Perstasiun $\left(\mathrm{gbk} / \mathrm{m}^{2}\right)$

Thalassia hemprichii merupakan jenis lamun dengan nilai biomassa total perjenis paling tinggi dan disusul oleh jenis Cymodocea rotundata dan Enhalus acoroides (Gambar 4). Thalassia hemprichii memiliki kandungan biomassa total paling tinggi baik di atas maupun di bawah substrat dibandingkan jenis lainnya yang ditemukan pada tiga stasiun penelitian pada perairan Pantai Nusa Lembongan.

Kandungan total biomassa jenis Thalassia hemprichii di atas substrat sebesar $582,90 \mathrm{gbk} / \mathrm{m}^{2}$ dan di bawah substrat sebesar $1201,60 \mathrm{gbk} / \mathrm{m}^{2}$, sedangkan total biomassa jenis Cymodocea rotundata sebesar $126,17 \mathrm{gbk} / \mathrm{m}^{2}$ di atas dan bawah substrat sebesar 221,39 gbk $/ \mathrm{m}^{2}$ sedangkan untuk jenis Enhalus acoroides memiliki nilai kandungan biomassa total di atas substrat sebesar $34,61 \mathrm{gbk} / \mathrm{m}^{2}$ dan bawah substrat yaitu sebesar $181,62 \mathrm{gbk} / \mathrm{m}^{2}$.

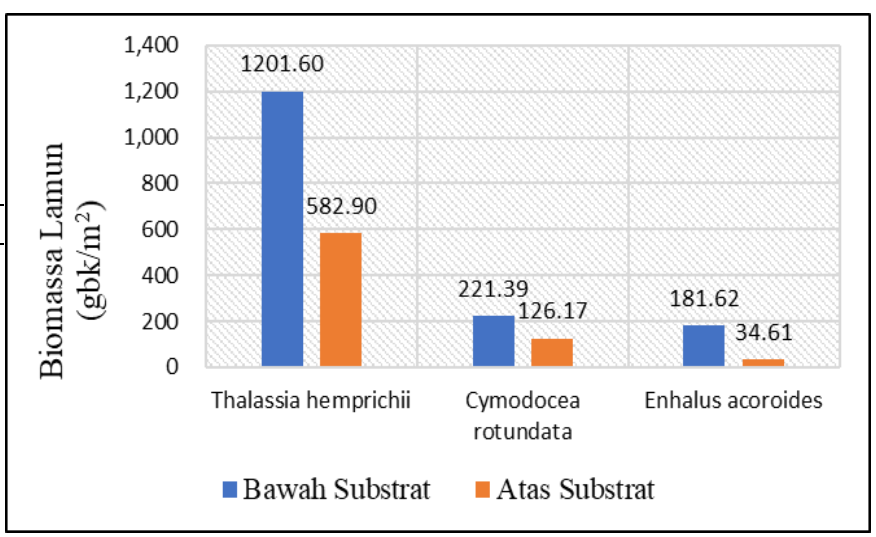

Gambar 4. Total Biomassa Perjenis Lamun $\left(\mathrm{gbk} / \mathrm{m}^{2}\right)$

Persentase total biomassa lamun perstasiun penelitian di atas dan bawah substrat di perairan Pantai Nusa Lembongan disajikan pada Gambar 5.

Persentase keseluruhan biomassa lamun di bawah substrat yaitu sebesar $68 \%$ atau sebesar $1604,62 \mathrm{gbk} / \mathrm{m}^{2}$ sedangkan untuk persentase keseluruhan total biomassa lamun di atas substrat sebesar $32 \%$ atau sebesar 743,68 gbk $/ \mathrm{m}^{2}$ 


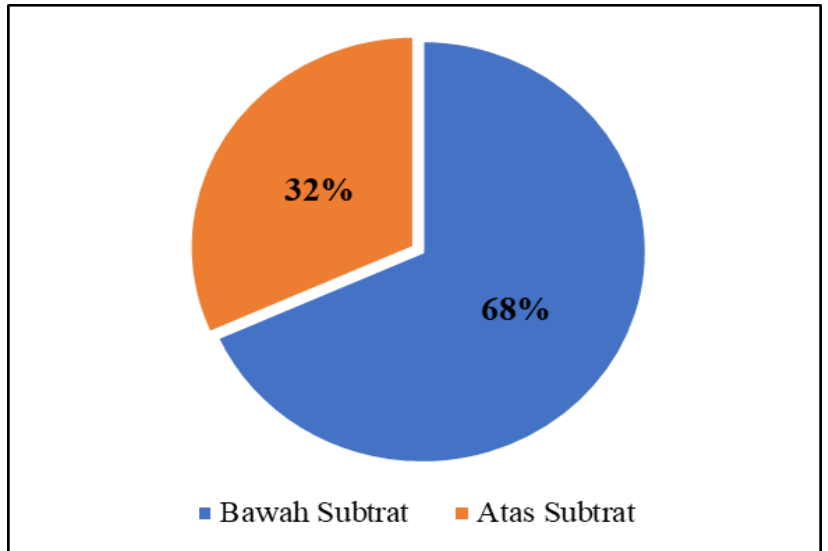

Gambar 5. Persentase Keseluruhan Biomassa Lamun Bawah dan Atas Substrat

\subsection{Kandungan Karbon dan Estimasi Simpanan Karbon}

\subsubsection{Kadar Baham Organik dan Kadar Abu}

Rata - rata nilai kadar bahan organik dan nilai kadar abu dari semua sampel lamun yang telah dianalisis, menunjukan bahwa rata - rata nilai kadar bahan organik di bagian atas substrat lebih tinggi daripada nilai kadar abu yaitu sebesar $75,5 \%$ sedangkan nilai rata - rata kadar abu sebesar 24,48\% (Gambar 6). Sementara itu untuk bagian bawah substrat nilai rata - rata nilai kadar bahan organik dan nilai kadar abu tidak jauh berbeda dan hampir sama dengan bagian atas substrat, rata - rata nilai kadar bahan organik di bagian bawah substrat sebesar $74,44 \%$ dan untuk rata - rata nilai kadar abu sebesar $25,45 \%$.

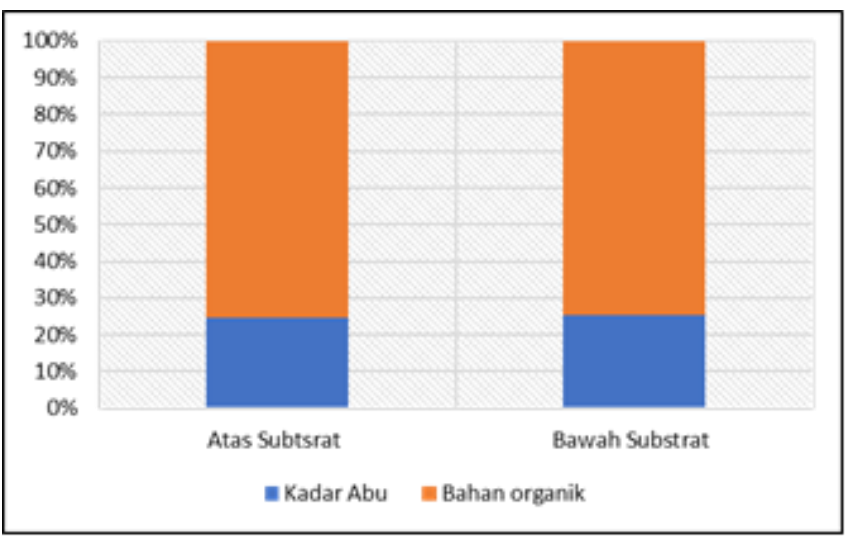

Gambar 6. Rata - rata Nilai Kadar Abu dan Nilai Kadar Bahan Organik dari 27 titik pengamatan

\subsubsection{Kandungan Karbon}

Setelah dilakukan analisis nilai kandungan karbon lamun dengan metode pengabuan pada semua sampel lamun yang dianalisis pada 27 titik pengamatan didapat bahwa kandungan karbon atas substrat lebih redah dibandingkan bawah sustrat.

Rata - rata nilai karbon yang terkandung di bagian bawah substrat sebesar $1,73 \mathrm{~g} \mathrm{C} / \mathrm{g}$ sedangkan untuk rata- rata nilaikarbon yang terkandung di bagian atas substrat sebesar 0,84 g C/g (Gambar 7).

\subsubsection{Estimasi Total Simpanan Karbon}

Estimasi total simpanan karbon pada penelitian ini didapat dari hasil rata - rata perhitungan karbon permeter persegi yang kemudian dikonversikan ke luasan area lamun untuk bagian atas

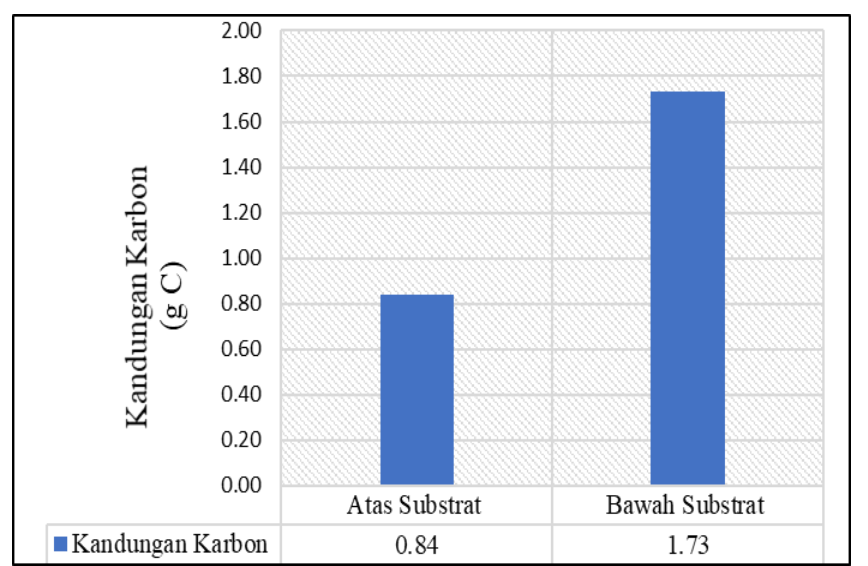

Gambar 7. Rata-rata Nilai Kandungan Karbon (gC) Atas Substrat dan Bawah Substrat pada 27 Titik Pengamatan

dan bawah substrat sehingga didapatkan estimasi total simpanan karbon lamun di Perairan Pantai Nusa Lembongan.

Rata - rata kandungan karbon permeter persegi di bagian bawah substrat sebesar $52,67 \mathrm{gC} / \mathrm{m}^{2}$ sedangkan untuk rata - rata kandungan karbon permeter persegi di bagian atas substrat sebesar 21,08 $\mathrm{gC} / \mathrm{m}^{2}$.

Luasan area lamun yang digunakan merujuk Astaman (2019) yang menyatakan bahwa perairan Pantai Nusa Lembongan memiliki luasan area padang lamun yaitu 89,64Ha.

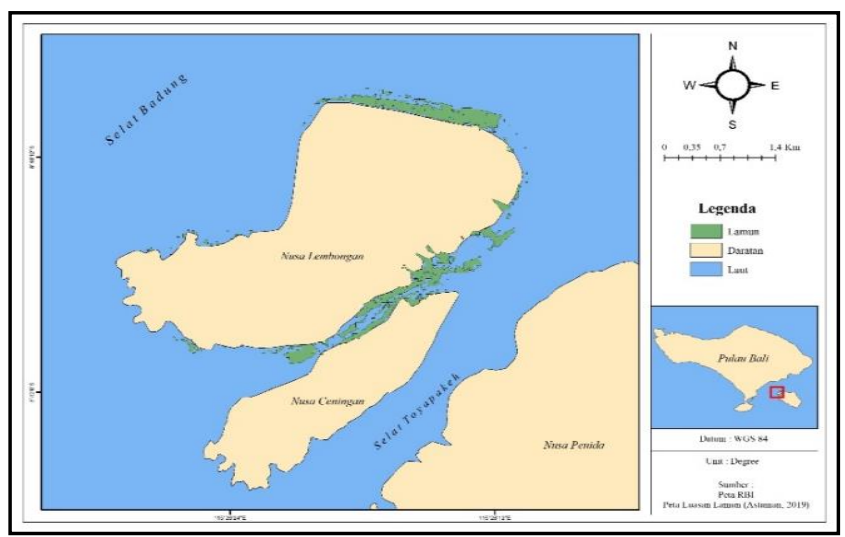

Gambar 8. Peta Distribusi Sebaran Lamun (Astaman,2019)

Estimasi total simpanan karbon di bagian bawah substrat sebesar $71 \%$ atau 47,12 ton karbon lebih tinggi dibanding atas substrat sebesar $29 \%$ atau 18,86 ton karbon, dengan total simpanan karbon di Perairan Pantai Nusa Lembongan sebesar 65,98 ton karbon dengan rata - rata stok karbon sebesar 0,73 ton/ha (Gambar 9).

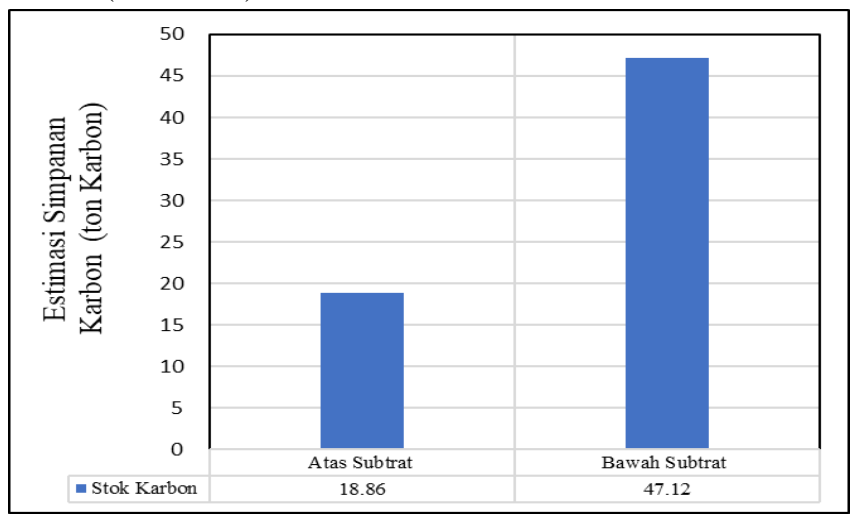

Gambar 9. Estimasi Simpanan Karbon (ton) 


\section{Pembahasan}

\subsection{Komposisi Jenis dan Kerapatan Lamun}

Jenis lamun Thalassia hemprichii dan Cymodocea rotundata mempunyai nilai komposisi jenis dan kerapatan tinggi dan ditemukan di semua stasiun penelitian, tingginya komposisi jenis dan kerapatan lamun ini karena pada 27 titik pengamatan didominasi oleh substrat pasir dan pasir berlumpur. Menurut Setiawan et al. (2012) jenis lamun Thalassia hemprichii dan Cymodocea rotundata umumnya dapat hidup dengan baik pada substrat berpasir dan lumpur berpasir, sedangkan jenis lamun Enhalus acoroides merupakan lamun yang memiliki nilai kerapatan paling rendah dari tiga stasiun penelitian dan hanya ditemukan di stasiun 2 pada titik pengamatan yang dekat dengan ekosistem mangrove, rendahnya nilai kerapatan lamun jenis Enhalus acoroides dikarenakan jenis ini mempunyai morfologi lebih besar dibandingkan jenis lamun yang lain. Hasil tersebut sesuai dengan pernyataan Yunitha (2015), bahwa lamun yang morfologinya besar cenderung memiliki nilai kerapatan yang rendah dibandingan lamun dengan morfologi yang kecil.

Titik pengamatan 2.7, 2.8 dan 2.9 pada stasiun 2 merupakan titik yang dekat dengan ekosistem mangrove dengan substrat lumpur berpasir dimana hanya pada tiga titik ini yang ditemukan jenis Enhalus acoroides dari total 27 titik pengamatan. Enhalus acoroides umumnya lebih dominan hidup pada substrat berlumpur halus dengan perairan relatif tenang (Wangkanusa et al., 2017), perairan yang dekat dengan ekosistem mangrove cenderung karakteristik perairannya lebih tenang, hal tersebut dikarenakan sistem perakaran mangrove yang mampu meredam arus dan gelombang (Fahruddin et al., 2017).

\subsection{Biomassa Lamun}

Nilai biomassa lamun di bawah substrat lebih tinggi dibandingkan di atas substrat diketiga stasiun penelitian. Tasabaramo et al. (2015) menyatakan nilai biomassa yang tinggi pada bagian bahwa substrat berasal dari sebagian hasil fotosintesis berupa material organik yang disimpan pada rhizoma dan akar lamun hal tersebut dilakukan agar daya erat rhizoma dan akar pada substrat menjadi kuat sehingga lamun dapat bertahan dari arus dan gelombang laut. Rhizoma dan akar lamun diketahui dapat menyerap banyak unsur hara yang berada pada substrat dimana hal tersebut juga mempengaruhi besarnya nilai biomassa pada bagian substrat lamun (Christon et al., 2012).

Thalassia hemprichii merupakan jenis lamun dengan nilai biomassa tertinggi di antara dua jenis lain yang ditemukan baik di bagian bawah substrat maupun atas substrat. Azizah et al. (2017) menyatakan bahwa selain morfologi lamun jumlah tegakan lamun juga mempengaruhi nilai biomassa lamun di suatu perairan, dimana semakin banyak tegakan lamun maka semakin besar biomassa dari lamun tersebut. Hal serupa juga dinyatakan oleh Simon \& Rifai, (2013) nilai kerapatan lamun dengan biomassa lamun akan berbanding lurus, dimana nilai kerapatan lamun yang semakin tinggi di suatu perairan maka nilai dari biomassa lamun akan semakin tinggi.

Biomassa lamun di atas substrat memiliki persentase lebih kecil dibanding biomassa di bawah substrat. Rustam et al. (2014) mengemukakan bahwa pada umumnya biomassa lamun sebagian besar terdapat di bagian bawah substrat. Morfologi dari rhizoma dan akan lamun sangat mempengaruhi tingginya nilai kandungan biomassa di bagian bawah substrat (Indriani et al., 2017).

\subsection{Kandungan Karbon dan Estimasi Simpanan Karbon}

Nilai kadar abu di atas substrat dan bawah substrat merupakan hasil dari penguapan selama proses pengabuan yang menandakan bahwa terdapat kandungan bahan mineral pada sampel lamun (Handayani et al., 2016). Kerapatan lamun juga dapat mempengaruhi kandungan bahan organik, dimana nilai kerapatan lamun yang tinggi dapat mengikat banyak bahan organik yang berada di perairan tersebut (Riniatsih (2016).

Berdasarkan hasil perhitungan kandungan karbon yang telah dilakukan, dapat dijelaskan secara keseluruhan stok karbon lamun di Perairan Pantai Nusa Lembongan pada bagian bawah substrat (rhizoma dan akar) lebih besar dibandingkan pada bagian atas substrat (daun). Kandungan karbon yang terdapat pada lamun merupakan penggambaran besarnya penyerapan $\mathrm{CO}_{2}$ di udara yang kemudian dimanfaatkan oleh lamun untuk melakukan proses fotosintesis dimana hasil penyerapan $\mathrm{CO}_{2}$ tersebut akan disimpan oleh lamun dalam bentuk biomassa. Tingginya nilai kandungan karbon di bagian bawah substrat akan terakumulasi di dalam sedimen, hal tersebut disebabkan materi biomassa yang berada di bawah substrat berbentuk biomassa padat dibanding materi biomassa atas substrat (Supriadi et al., 2014). Widyasari \& Saharjo, (2010) menyatakan besarnya nilai biomassa berhubungan erat dengan potensi kandungan karbon pada lamun.

Berdasarkan hasil yang didapat, pendugaan kontribusi stok karbon terbesar disumbangkan oleh jenis lamun Thalassia hemprichii. Pendugaan konstribusi tersebut berkaitan dengan tingginya nilai kerapatan serta besarnya nilai biomassa lamun jenis tersebut. Rahmawati (2011) menyatakan bahwa antara estimasi simpanan karbon memiliki hubungan erat dengan biomassa lamun, dimana estimasi simpanan karbon akan mengalami peningkatan sejalan dengan peningkatan biomassa lamun. Menurut Kaswadji et al. (2012) nilai estimasi simpanan karbon di bagian bawah substrat lebih tinggi dibanding atas substrat, hal ini dikarenakan jaringan di bagian bawah substrat tidak terpengaruh oleh adanya perubahan fisik pada lingkungan dibandingkan dengan jaringan yang berada di atas substrat.

Pada penelitian ini total estimasi simpanan karbon sebesar 65,98 ton karbon dengan estimasi simpanan karbon rata - rata sebesar 0,73 ton/ha dengan luas ekosistem lamun sebesar 89,46 Ha, dibandingkan dengan penelitian Indriani et al. (2017) di Pesisir Pulau Bintang, Kepulauan Riau dimana estimasi simpanan karbon lamun di perairan tersebut mencapai $820.052,48$ ton karbon jauh lebih kecil dari hasil yang didapatkan pada penelitian ini. Tingginya estimasi simpanan karbon di perairan tersebut dikarenakan Pesisir Pulau Bintang memiliki hamparan ekosistem lamun yang sangat luas yaitu sebesar 2600 Ha. Penelitian yang dilakukan oleh (Rahmawati, 2011) menunjukan estimasi simpanan karbon di Pulau Pari, Kepulauan Seribu, Jakarta lebih besar mencapai 67,21 ton C, dengan luas hamparan padang lamun 32,706 ha, tingginya estimasi simpanan karbon di Pulau Pari dikarenakan jenis lamun yang ditemukan lebih banyak dan didominasi oleh lamun jenis Thalassia hemprichii dan Enhalus acoroides dimana jenis ini mempunyai morfologi yang besar sehingga memiliki kandungan karbon yang tinggi. Gunawan et al. (2019) menyebutkan simpanan karbon di Pulau Semak Daun, Kepulauan Seribu, sebesar 1,84 ton C dengan luas lamun sebesar 9,1 ha.

Ekosistem lamun di perairan Pantai Nusa Lembongan memiliki fungsi penting yaitu sebagai carbon sink dimana simpanan karbon yang terkandung pada biomassa lamun akan dialirkan dan disimpan kedalam sedimen, karbon di bawah substrat sangat penting karena akan terkubur dan terkunci didalam sedimen (Graha et al., 2016). Kaitan ekosistem lamun dalam mengurangi dampak perubahan iklim yakni lamun sebagai penyimpan karbon melalui proses fotosintesis.

Padang lamun di perairan Pantai Nusa Lembongan termasuk ke dalam kawasan pariwisata, berdasarkan pengamatan di lokasi penelitian terlihat bahwa sebagian arealnya dijadikan sebagai lokasi penempatan boat/perahu, yang dimana hal tersebut dapat 
menutupi dan merusak lamun. Kerusakan tersebut semakin meluas karena posisi kapal yang terus berpindah setiap pantai mengalami surut. Menurut Wirawan (2014) kegiatan manusia di wilayah pesisir seperti rekreasi atau wisata pantai dan aktivitas lainya dapat mempengaruhi keberadaan lamun secara langsung atau tidak langsung.

Merujuk dari hal tersebut diperlukan adanya sistem pengelolaan ekosistem pesisir secara terpadu terutamanya pada ekosistem lamun, agar fungsi ekologi dan biologisnya dapat berjalan seimbang, serta dapat mempertahankan keberadaan ekosistem lamun dan dapat mengoptimalkan peran ekosistem lamun sebagai carbon sink, mengingat konstribusi ekosistem lamun dalam upaya mengurangi efek pemanasan global guna perbaikan kualitas lingkungan.

\section{Kesimpulan}

Estimasi simpanan karbon di bagian atas substrat (daun) yaitu $29 \%$ atau sebesar 18,86 ton karbon nilai ini lebih kecil dibandingkan nilai estimasi simpanan karbon di bagian bawah substrat (rhizoma dan akar) yaitu $71 \%$ atau sebesar 47,12 ton karbon. Estimasi total simpanan karbon lamun sebesar 65,98 ton dengan luas sebaran lamun sebesar 89,46 ha di Perairan Pantai Nusa Lembongan.

\section{Ucapan Terimakasih}

Terima kasih kapada Laboratorium Ilmu Kelautan Fakultas Kelautan dan Perikanan serta Laboratorium Tanah Fakultas Peternakan Universitas Udayana yang telah memfasilitasi penulis selama melakukan penelitian ini. Sebagian dari penelitian ini didanai oleh hibah Penelitian Unggulan Udayana (PUU), Universitas Udayana, nomor 446/UN14.2.13.II/LT/2019, tanggal 29 Maret 2019.

\section{Daftar Pustaka}

[KKP] Kawasan Konservasi Perairan. (2010). Profil Kawasan Konservasi Perairan (KKP) Nusa Penida, Kabupaten Klungkung, Provinsi Bali. (KKP : 75)

Astaman D.M.K.P. (2019). Pemetaan Habitat Dasar Perairan Dangkal Menggunakan Citra Satelit SPOT-7 di Pulau Nusa Lembongan, Bali [skripsi]. Bukit Jimbaran : Fakultas Kelautan dan Perikanan, Universitas Udayana. 48 hal.

Azizah, E., Nasution, S., \& Ghalib, M. (2017). Biomasso and Density of Seagrass Enhalus acoroides In the Village Waters Jago-Jago of Tapanuli Tengah North Sumatera Province (Doctoral dissertation, Riau University).

Azkab, M.H. (1999). Kecepatan Tumbuh dan Produksi Lamun dari Teluk Kuta Lombok. Di dalam: Soemodihardjo, Arinardi OH, Aswandy I, Editor. Dinamika Komunitas Biologis pada Ekosistem Lamun di Pulau Lombok Indonesia. Jakarta: Pusat Penelitian dan Pengembangan Oseanologi, Lembaga Ilmu Pengetahuan Indonesia. hlm 26-33.

Campbell, J. E., Lacey, E. A., Decker, R. A., Crooks, S., \& Fourqurean, J. W. (2015). Carbon storage in seagrass beds of Abu Dhabi, United Arab Emirates. Estuaries and Coasts, 38(1), 242-251.

Christon, C., Djunaedi, O. S., \& Purba, N. P. (2012). Pengaruh tinggi pasang surut terhadap pertumbuhan dan biomassa daun lamun Enhalus acoroides di Pulau Pari Kepulauan Seribu Jakarta. Jurnal Perikanan dan Kelautan Unpad, 3(3), 124821

Fachrul M.F. (2007). Metode Sampling Bioekologi. PT Bumi Aksara : Jakrarta $208 \mathrm{Hal}$

Fahruddin, M., Fredinan, Y., \& Isdradjad, S. (2017). Kerapatan dan penutupan ekosistem lamun di pesisir Desa Bahoi, Sulawesi Utara. Jurnal Ilmu dan Teknologi Kelautan Tropis, 9(1), 375-383.

Fourqurean, J. W., Duarte, C. M., Kennedy, H., Marbà, N., Holmer, M. Mateo, M. A., \& Serrano, O. (2012). Seagrass ecosystems as a globally significant carbon stock. Nature geoscience, 5(7), 505-509.
Githaiga, M. N., Kairo, J. G., Gilpin, L., \& Huxham, M. (2017). Carbon storage in the seagrass meadows of Gazi Bay, Kenya. PloS one, 12(5).

Graha, Y. I., Arthana, I. W., \& Karang, I. W. G. A. (2016). Simpanan karbon padang lamun di kawasan Pantai Sanur, Kota Denpasar. Ecotrophic: Jurnal Ilmu Lingkungan (Journal of Environmental Science), 10(1), 4653.

Gunawan, J. V., Parengkuan, M., \& Zulpikar, F. (2019). Estimasi Stok Karbon pada Biomassa Lamun di Pulau Semak Daun, Kepulauan Seribu. OLDI (Oseanologi dan Limnologi di Indonesia), 4(2), 89-99.

Handayani, D. R., Armid, A., \& Emiyarti, E. (2016). Hubungan Kandugan Nutrien Dalam Substrat Terhadap Kepadatan Lamun di Perairan Desa Lalowaru Kecamatan Moramo Utara. Jurnal Sapa Laut (Jurnal Ilmu Kelautan), 1(2).

Hartanti R, Pratikto I., \& Pratawi T. N. (2017). Biomassa dan Estimasi Simpanan Karbon pada Ekosistem Padang Lamun di Pulau Menjangan Kecil dan Pulau Sintok, Kepulauan Karimunjawa. Buletin Oseanografi Marina Vol 6 No 1:74-81

Helrich K. (1990). Method of Analysis of the Association of Official Analytical Chemists, Fifteenth Edition. Virginia: Wilson Boulevard. 771 hal.

Howard J, Hoyt S, Isensee K, Pidgeon E \& Telszewski M. (2014). Coastal blue carbon: methods for assessing carbon stocks and emissions factors in mangroves, tidal salt marshes, and seagrass meadows (Virginia USA: Conservation International, Intergovernmental Oceanographic Commission of UNESCO, International Union for Conservation of Nature. Arlington)

Indriani, Wahyudi A, \& Yona D. (2017). Cadangan Karbon di Area Padang Lamun Pesisir Pulau Bintan, Kepulauan Riau. Oseanologi dan Limnologi di Indonesia 2(3): 1-11

Irawan A. (2017). Potensi Cadangan dan Serapan Karbon oleh Padang Lamun di bagian Utara dan Timur Pulau Bintan. Oseanologi dan Limnologi di Indonesia 2017 2(3): 35-48

Kaswadji, R. F., Bengen, D. G., \& Hutomo, M. (2012). Produktivitas komunitas lamun di Pulau Barranglompo Makassar. Jurnal Akuatika, $3(2)$.

Kennedy, H. \& Bjork, M. (2009). Seagrass Meadows. In: Laffoley D.D.A and Grimsditch G. (Eds). The Management of Natural Coastal Carbon Sinks. Glan: IUCN.

Khairunnisa., Setyobudiandi, I., \& Boer, M. (2018). Estimasi Cadangan Karbon pada Lamun di Pesisir Timur Kabupaten Bintan. Jurnal Ilmu dan Teknologi Kelautan Tropis, 10(3), 639-650.

Khouw, A.S. (2009). Metode dan Analisa Kuantitatif dalam Bioekologi Laut. Jakarta: Pusat Pembelajaran dan Pengembangan Pesisir dan Laut

Pharmawati, M., Putra, I., Syamsuni, Y. F., \& Mahardika, I. G. N. K. (2015). Genetic diversity of Enhalus acoroides (L.) Royle from coastal waters of Pramuka Island, Lembongan Island, and Waigeo Island, Indonesia, based on microsatellite DNA. Advanced Science Letters, 21(2), 199-202.

Pramudya F.S., Wikantika K., \& Windupranata W. (2014). Satellite-based benthic habitat mapping using Landsat 8 in Nusa Lembongan and Nusa Ceningan Island. in : Proceedings of the 35th Coference on Remote Sensing (ACRS 2014) ; Nay Pyi Taw, 27-31 October 2014. hlm 716-721

Rahadiarta, I. K. V. S., Putra, I. D. N. N., \& Suteja, Y. (2018). Simpanan Karbon Pada Padang Lamun di Kawasan Pantai Mengiat, Nusa Dua Bali. Journal of Marine and Aquatic Sciences, 5(1), 1-10.

Rahman, F. A., Qayim, I., \& Wardiatno, Y. (2018). Carbon storage variability in seagrass meadows of Marine Poton Bako, East Lombok, West Nusa Tenggara, Indonesia. Biodiversitas Journal of Biological Diversity, 19(5), 1626-1631.

Rahmawati, S. (2011). Estimasi cadangan karbon pada komunitas lamun di Pulau Pari, Taman Nasional Kepulauan Seribu, Jakarta. Jurnal Segara, 7(1), 1-12.

Riniatsih, I. (2016). Distribusi Muatan Padatan Tersuspensi (MPT) di Padang Lamun di Perairan Teluk Awur dan Pantai Prawean Jepara. Jurnal Kelautan Tropis, 18(3), 121-126.

Rustam, A., Kepel, T. L., Afiati, R. N., Salim, H. L., Astrid, M., Daulat, A., Mangindan, P., Sudirman, N., Puspitaningsih, Y., Dwiyanti, D., \& Hutahaean, A. (2014). Peran Ekosistem Lamun Sebagai Blue Carbon Dalam Mitigasi Perubahan Iklim, Studi Kasus Tanjung Lesung, Banten. Jurnal Segara, 10(2), 107-117.

Setiawan, F., Harahap, S. A., Andriani, Y., \& Hutahaean, A. A. (2012). Deteksi perubahan padang lamun menggunakan teknologi penginderaan jauh dan kaitannya dengan kemampuan menyimpan karbon di Perairan Teluk Banten. Jurnal Perikanan Kelautan, 3(3)

Simon, I. P., \& Rifai, H. (2013). Struktur komunitas padang lamun di perairan Pulau Mantehage, Sulawesi Utara. Jurnal Ilmiah Platax. 1(4), 177-186. 
Supriadi, S., Kaswadji, R. F., Bengen, D. G., \& Hutomo, M. (2014). Carbon Stock of Seagrass Community in Barranglompo Island, Makassar (Stok Karbon pada Komunitas Lamun di Pulau Barranglompo, Makassar). Ilmu Kelautan: Indonesian Journal of Marine Sciences, 19(1), 1-10.

Tasabaramo, I. A., Kawaroe, M., \& Rappe, R. A. (2015). Laju Pertumbuhan, Penutupan Dan Tingkat Kelangsungan Hidup Enhalus acoroides Yang Ditransplantasi Secara Monospesies Dan Multispesies. Jurnal Ilmu Dan Teknologi Kelautan Tropis, 7(2), 757-770.

Wangkanusa, M. S., Kondoy, K. I., Pi, S., \& Si, M. (2017). Identifikasi Kerapatan dan Karakter Morfometrik Lamun Enhalus acoroides Pada Substrat yang Berbeda di Pantai Tongkeina Kota Manado. Jurnal Ilmiah Platax, 5(2), 210-220.

Widyasari, N. A. E., \& Saharjo, B. H. (2010). Pendugaan biomassa dan potensi karbon terikat di atas permukaan tanah pada hutan rawa gambut bekas terbakar di Sumatera Selatan. Jurnal Ilmu Pertanian Indonesia, 15(1), 41-49.

Wirawan, A. A. (2014). Tingkat Kelangsungan Hidup Lamun yang Ditransplantasi secara Multispesies di Pulau Barrang Lompo. Makassar: Universitas Hasanuddin.

Yunitha, A. (2015). Kandungan C-Organik pada Lamun Berdasarkan Habitat dan Jenis Lamun di Pesisir Desa Bahoi Kabupaten Minahasa Utara Sulawesi Utara (Doctoral dissertation, Tesis, Institut Pertanian Bogor, Bogor). 